\title{
高強勒性マグネシウム合金の環境軽負荷型 製造技術の開発
}

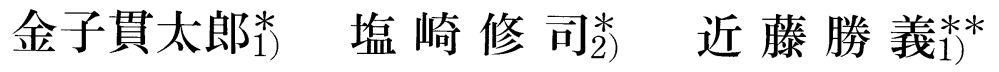 \\ 荻 沼秀 樹吕* 秋田亨***
}

\section{1. 緒言}

従来の Mg 合金においては, (1)アルミニウム合金レベル の高強度化が困難であり, (2)高強度化に伴う靱性(伸び)の低 下や，(3)最密六方構造に起因する低温での塑性加工性の問 題, さらには(4)急冷凝固法などによる高価な微粉末の利用に よるトータルコストの上昇と安全性の低下など，実用化を妨 げる様々な要因がある。なかでも，(1)と(2)は一般の多結晶材 料で見られる, 強度一勒性のトレードオフ・バランスゆえ, 従来の材料・プロセス設計では解決し難い課題である. また (3)に関しては, 特に押出加工や圧延加工を施した展伸材にお いて, 強い底面配向性を示すために加工方法そのものに起因 する課題である. そして, これらの課題は, 結果として $\mathrm{Mg}$ 合金部材のトータルコストを上昇させる。これまでに個々の 課題に対して，例えば，塑性加工法を利用した結晶粒の微細 化 ${ }^{(1)}$ や急冷凝固プロセスによる組織制御 ${ }^{(2)}$, 直接溶湯圧延法 なぞが検討されてきたが，全ての課題を同時に解決できるよ うな材料・プロセス技術の確立には未だ至っていない. 本研 究は, 低温域での成形加工性に優れた高強靱性マグネシウム $(\mathrm{Mg})$ 合金の環境軽負荷型製造プロセスの構築とその装置開 発を目的とする. 軽量化技術は, $\mathrm{CO}_{2}$ 排出量の削減などの 地球環境問題や原油価格の高騰に起因する省エネ問題などへ の有効な方策の一つである. なかでも，鉄鋼材料の約 $1 / 4$, アルミニウム合金の約 $2 / 3$ の低比重を有する Mg 合金は, 近年, 軽量化素材として着目され, 特に自動車用あるいは航

\footnotetext{
* 株式会社栗本鐵工所機械事業部 : 1)技師長

2)粉砕システム技術部部長

** 東京大学先端科学技術センター: 1) 特任助教授

2)リサーチフェロー

** 株式会社ゴーシュー成形技術グループ

Environmentally Benign Process of Wrought Magnesium Alloy with High Strength and High Ductility; Kantaro Kaneko*, Shuji Shiozaki*, Katsuyoshi Kondou**, Hideki Oginuma**, Toru Akita*** (*Kurimoto Ltd. **RCAST, The University of Tokyo. ${ }^{* * *}$ Gohsyu Corp.)

2005年10月26日受理
}

空機用部品をはじめとする移動体用構造部材としての実用化 ニーズも大きい.このような背景のもと, 本研究開発は, ま さに大気污染物質の排出抑制, 有限石化エネルギーの有効利 用など地球環境への負荷軽減技術を具現化する従来にないマ グネシウム展伸材の革新的製造プロセス技術の構築と実用化 を目指すものである。

\section{2. 開発した製造プロセス・装置およびその特徵 優位性}

上記の課題を鑑み, 市場が求める実用化ニーズに対応でき るマグネシウム合金を，粉体技術と塑性加工法を基調とした 従来にない組織制御プロセスを開発することで, 低温での成 形加工性に優れた高強靱性・安価マグネシウム合金部材製造 プロセスおよび装置(ロールコンパクタ, Roll Compaction/ $\mathrm{RCP}$; 図 1)の開発に成功した ${ }^{(3)-(5)}$ 。ここで, 具体的な特 徵・優位性は次の通りである.

(1) $\mathrm{RCP}$ 加工で数ミリの粗大 $\mathrm{Mg}$ 原料粉体に対して双口 一ル压延(剪断·圧縮加工) と粉砕加工の繰り返しにより，1 $\mu \mathrm{m}$ 以下の超微細結晶粒を有するミリオーダーの粗粉末の創 製(安全性の確保)，粉体の不連続性を利用した圧延加工によ る集合組織の無秩序化の促進(底面配向性の抑制), 微細な金 属間化合物の動的析出を促進させ, 結晶粒の粗大化抑制之耐 熱性の向上，原料粉体への熱処理 $(\mathrm{T} 4 / \mathrm{T} 6)$ による繰り返し 加工回数の削減 (プロセスコストの低減).

(2) 上記の $\mathrm{RCP}$ 加工 $\mathrm{Mg}$ 粉体から押出 - 鍛造 · 圧延加工 によって得られたマグネシウム展伸材は, サブミクロン〜数 $\mu \mathrm{m}$ の微細結晶粒を有することで, 同一組成の展伸材に対し て引張強さ・耐力が $50 \sim 80 \%$ 増加し, 同時に双晶の発生を 抑制することで破断伸びは同等レベル $(15 \sim 25 \%)$ を有す る.したがって, 従来の金属材料の課題である強度一靶性の トレードオフ・バランスを大幅に改善できることを示唆し た。展伸材においても集合組織のランダム化を発現し，その 結果, $200^{\circ} \mathrm{C}$ 以下の 3 次元複雑鍛造加工を実現.さらに, $100 \sim 150^{\circ} \mathrm{C}$ 付近での低温塑性加工により板状展伸材から健 


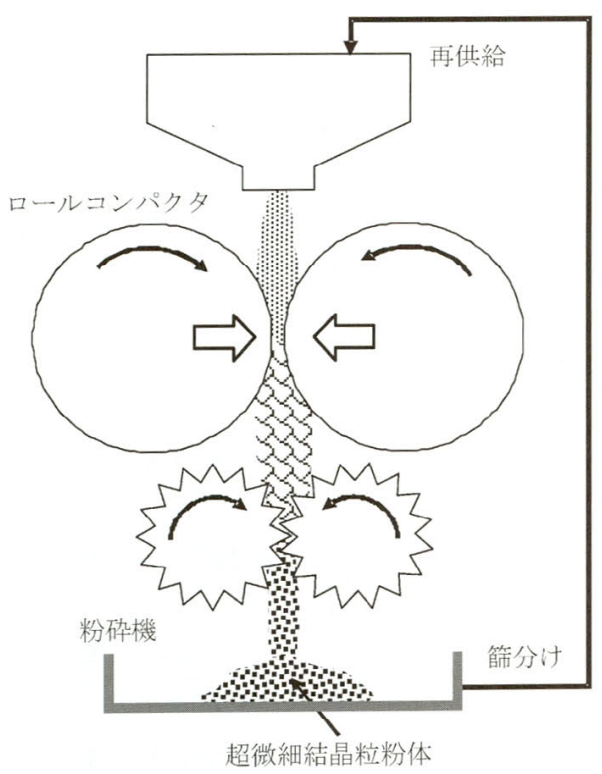

図 1 超微細結晶粒粉体の製造プロセス.

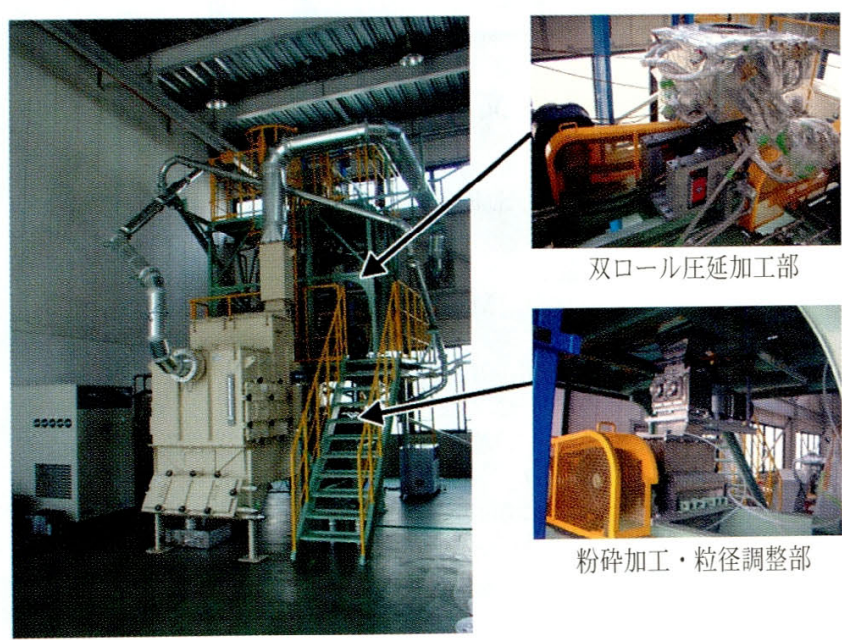

図 $2 \mathrm{Mg}$ 合金粉体量産用 $\mathrm{RCP}$ 加工装置.

全な部材創製が可能.

(3) 今回開発したRCP 加工装置(図 2)においては, 溶解 工程を一切経由しない粉体技術を基調とすることで, 本開発 装置に上る製造過程でのエネルギー消費量は動力原単位で約 $0.6 \sim 0.7 \mathrm{kWh} / \mathrm{kg}$ と従来の溶解·鋳造法の $1 / 20 \sim 1 / 30$ と小 さく, 顕著な省エネ効果を実証. 粉研加工条件とその後の排 出口のスクリーン径の管理によって, 排出される粉体の寸 法・形状を適正範囲内とすることで，双ロール間での粉体の 圧下率を制御し, 均質な加工歪の導入 ·蓄積を可能とした。 さらに全工程でミリ単位の粗粒 $\mathrm{Mg}$ 粉体を扱うことで安全 性に優れた製造プロセス・装置である.

\section{3. 成果と実用化状況}

粉体技術と塑性加工法を基調とした本開発プロセスおよび その製造装置により，従来のマグネシウム合金の実用化に抢 ける技術的・経済的課題を克服した. 具体的には, 次の通り

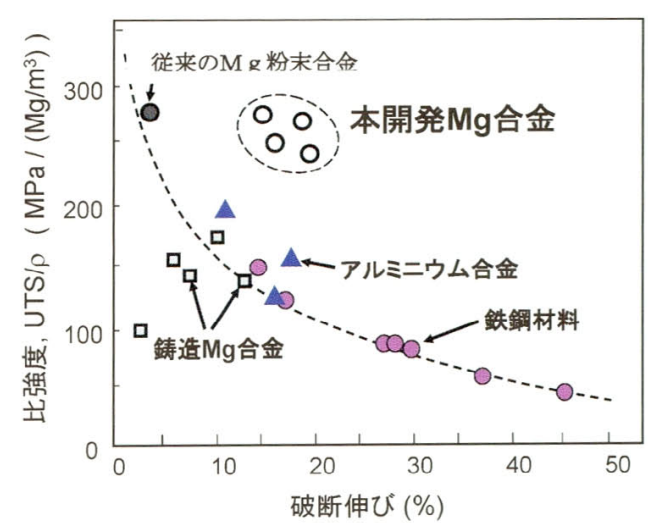

図 3 引張強さ一破断伸びの関係(従来材料との比較).
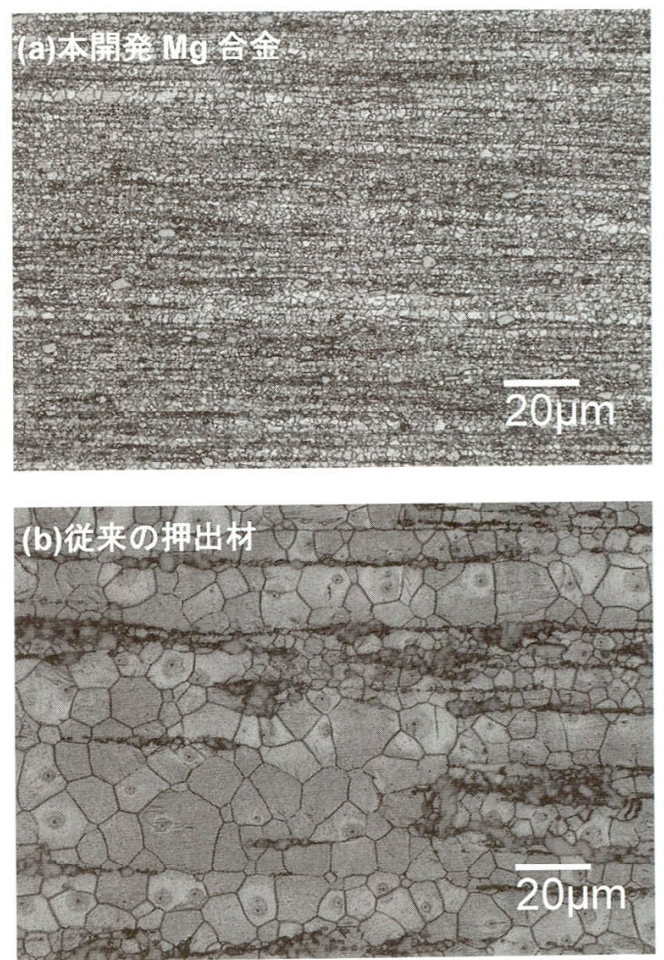

図 4 AZ31 合金押出材での結晶粒比較。 ( $\mathrm{a} ;$ 本開発製法, b ; 従来製法).

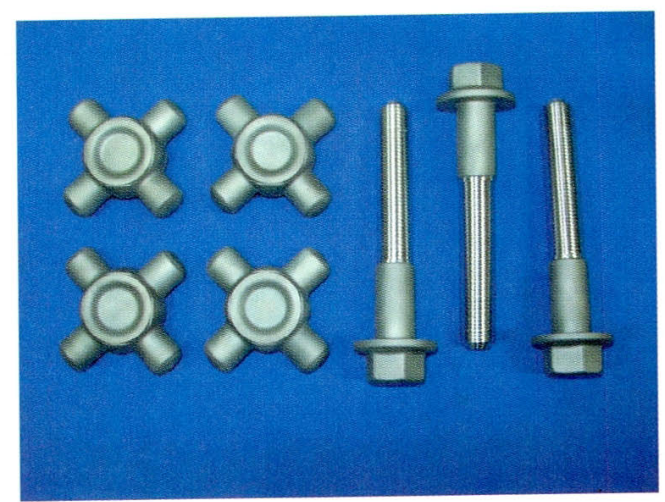

図 5 低温鍛造加工サンプルの一例. 
表 1 本開発 $\mathrm{Mg}$ 関連製品の売上実績および計画.

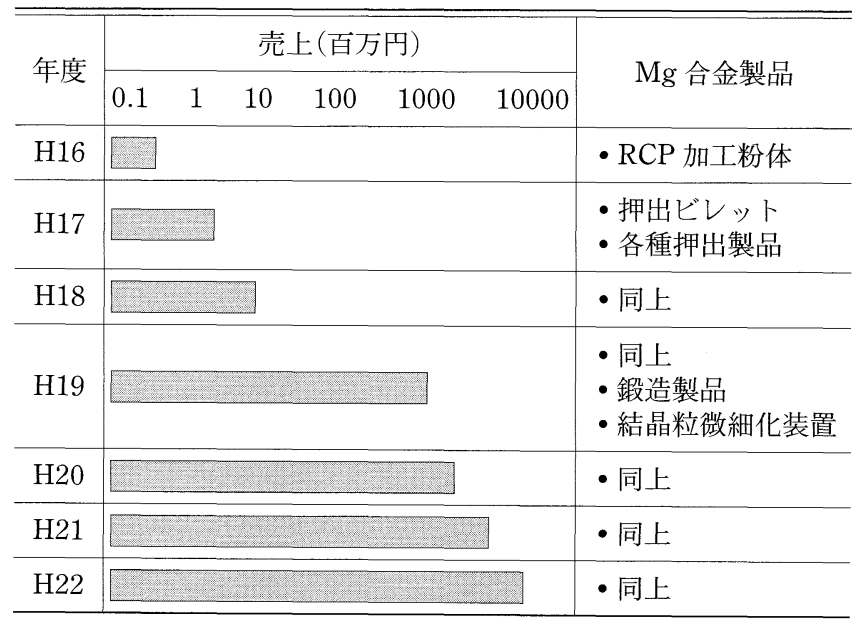

である・

(1) 既存の $\mathrm{Mg}$ 合金に適用した場合でも，微細組識を有 する強度・靱性に優れた大型展伸材を創製.

例. AZ31 合金板材; 引張強さ 385 400 MPa 以上, 耐力 $350 \mathrm{MPa}$ 以上，伸び 15２0\%：図 3，4.

(2) 安全性に優れ，かつ低コスト・環境低負荷を実現した $\mathrm{Mg}$ 合金粉体加工プロセス・装置である.

(3) 優れた低温塑性加工性 (例. $200^{\circ} \mathrm{C}$ での 3 次元複雑形 状鍛造(図 5), $150^{\circ} \mathrm{C}$ 以下での板加工成形).

(4) 粉体, 固化ビレット，展伸材および製造装置の販売実 績および売上計画(表 1).

\section{4. 結言}

これまでの板やパイプなどのマグネシウム合金展伸材は， 低温での加工性に劣るために低生産性による 2 次加工コス トの増加が，マグネシウム合金の広範囲での実用化・部材化 を抑制しているのも事実である，これに対して，本技術成果 によれば，高強度・高靱性を維持しながら，低温での成形加 工や鍛造加工を可能とする。これによりマグネシウム合金部
材としての普及を図ることを側面的に支援するものと期待で きる. また，今回開発した RCP 加工プロセスは，アルミニ ウム合金や銅合金などの非鉄金属素材にも適用でき，これに より各素材に拝いても同様の高付加価值化効果 (高強度 ·高 鞁性化)が実現できる。これにより海外の安価な素形材に比 べて，性能上の差別化が可能となる。

\section{5. 特 許}

本研究開発に関しては以下の 4 件の特許を出願済みであ る.

(1) 特許の名称 合金粉体原料抢よびその製造方法(国内 および PCT 国際出願)

(2) 特許の名称 合金粉の結晶粒微細化装置(国内出願)

(3) 特許の名称 粉体の結晶粒微細化方法 (国内出願)

(4) 特許の名称 マグネシウム合金粉体原料, 高耐力マグ ネシウム合金, マグネシウム合金粉体原 料の製造方法および高耐力マグネシウム 合金の製造方法 (国内出願)

\section{文献}

(1) Y. Yoshida, L. Cisar, S. Kamado and Y. Kojima: Mater. Trans., 44(2003), 468-475.

(2) 井上明久, 河村能人, 松下光英, 林 健太郎 : 高強度ナノ結晶 マグネシウム基合金, Mater. Sci. Forum, 386-388(2002), 509-518.

（3）近藤勝義, 荻沼秀樹, 川端健詞, 住田雅樹, 秋田 亨, 金子 貫太郎：“RCPプロセスによる微細結晶粒を有する粗大マグ ネシウム合金粉体の特性”, 軽金属学会第109回秋季大会, 千 葉工業大学, (2005).

(4) K. Kondoh, H. Oginuma, M. Sumida, S. Shiozaki and Y. Goho: High-Strengthened Magnesium Alloys by Employing Coarse Powder with Refined Grains, 1st Asian Symposium on Magnesium Alloys, Jeju-do, Korea, (2005).

( 5 ) K. Kondoh, H. Oginuma, K. Kawabata, K. Kaneko, T. Akita and S. Kamado: Wrought Magnesium Alloys in Employing Grain-refined Coarse Magnesium Alloy Powder via RCP Process, Mater. Trans. (Submitted). 